Sofija GEORGIEVSKA

UDK: 159.944.4:373.5.011.3-051(497.7)

Original research article

\title{
PROFESSIONAL BURNOUT, SOURCES OF STRESS AND LIFE SATISFACTION AT EDUCATIONAL STAFF IN THE SECONDARY EDUCATION IN THE REPUBLIC OF MACEDONIA
}

\begin{abstract}
The aim of this research was to answer the question about whether there is a difference regarding the professional burnout, the sources of stress and life's pleasure among the teachers working in the secondary schools in RM associated with the place of work, the sex and the length of service. The specimen includes 440 educational workers, out of which 220 are from the secondary schools in the interior of the RM and 220 are from the secondary schools in Skopje. The research was carried out in the period between February and April 2018.

The results show that there is not a statistically significant difference in the level of manifestation of the professional burnout, the sources of stress and life's pleasure between the teachers working in the interior secondary schools in RM and the ones working in Skopje. The research has shown that the age and length of service considerably correlate with the professional burnout and the level of experienced stress, whereby the older group with the longest length of service is the most susceptible to the influence of the professional burnout and the sources of stress in the teachers.
\end{abstract}

Key words: PROFESSIONAL BURNOUT, SOURCES OF STRESS AND LIFE'S PLEASURE

\section{Introduction}

Living in time of constant technical and technological development, the need for modern education is increasingly imposed, as well as the willingness to follow, adapt and modernize the teaching contents, methods and techniques, and develop a climate in which each participant in the educational process will feel useful, fulfilled and creative, to be not only a passive part, but an active actor within a large and complex whole called "education".

The studying of the sources of stress and professional burnout can contribute to a clearer understanding of the current state of education in the Republic of Macedonia and enable further intervention and undertaking of certain measures that will enable the reduction or elimination of the negative impacts, and thus increase the life sat- 
isfaction among the teaching staff in the secondary education that will enable increase of the efficiency and the quality of the educational process.

The contemporary society in the 21st century is characterized by rapid scientific and technological development which conditioned extended working hours, which means that the modern human is spending more than 8 hours at his workplace. Prolonged working hours and the pace of life contribute to increased stress. People often perceive their work as stressful to the extent that it reflects on their motivation and enthusiasm for work. People are losing the desire to come back to work, and one of the ultimate negative consequences of work stress, according to Havelka (according to Andelković, 2012), is the syndrome of burning.

The term "burnout", has Anglo-Saxon origin and as such is used in many countries in the world and even in our country as well. It was introduced for the first time by Freudenberger in 1974 in order to describe the prevention of effective functioning and working, which is a result of prolonged and stressful work associated with stress (Dorman, 2003).

Professional burnout is usually a reaction to professional stress that appears as a consequence of the inability to adequately adjust the demands that the workplace sets. According to Ekstend and Fagerberger (2005), Angelovich (2012) notes that the syndrome of burnout appears in those individuals who have been exposed to extraordinary psychosocial stressors in the workplace for a long time, and people who are committed to their work will realize that their sacrifice was unsuccessful, because the desired goals and effects were not achieved. One of the reasons for the emergence of emotional exhaustion is the overwhelming expectations on the one hand, and the extensive and excessive working obligations that the employees place in front of themselves on the other hand, with the appearance of a sense of emotional exhaustion and a feeling of inadequate working environment. At the same time, the attitude toward the collective changes and the colleagues, as well as the so-called "Faceless relationship" is created by alienation, which is a consequence of the indifferent and negative attitude towards the professional stressors. There is also a decrease in the work efficiency and the personal engagement that increases the tendency toward self-mutilation. It all conditions and causes a loss of sense of ability, achievement and productivity of work (Maslach et al., 2001).

Previous analyses related to stress indicate that they are of a multifactorial nature and depend on the individual, interpersonal and organizational factors. How certain stimuli will affect someone to a large extent depends on the level of cognitive processing, which is related to personal goals, beliefs, attitudes, etc. Chabarkappa (Чабаркапа, 2009) notes that many studies related to the study of the combustion syndrome are viewed by teachers as a homogeneous group, thus neglecting the different approaches to work, individual differences, and coping strategies that employees apply in overcoming professional stress.

In the last few decades, "stress" is one of the most studied concepts. Pointing the focus of attention towards stress and its manifestations, various theoretical appro- 
aches were developed that put emphasis on the physiological or psychological manifestations from a different point of view. One of the first stress theories is the one of Walter Kanoeva, which includes physiological and psychological reactions. According to this theory, stress is understood as an emotional and physiological response to danger. As a result, the organism can accordingly react in two ways: by opposing and fighting or by escaping. One of the most prominent advocates of the physiological model of stress and the father of modern stress, Sely, categorizes stress as a general adaptive syndrome that takes place through the hypothalamic - pituitary - adrenal axis, on the basis of which the stress reaction is accompanied by a rise in the concentration of cortisol in the plasma.

However, the "general adaptation model" was criticized for neglecting psychological factors in shaping the responses to external danger, as well as for the "uniformity of the stress responses".

Educational work is a complex system of interconnected educational activities that does not only entail the teaching of students, but it is also a complex system of communication with the students, the parents, the collective and the management of the school. Within the framework of the realization of the teaching activity, the teacher is the one who must pay attention to the implementation and the respect of the code of ethics, the one to preserve the ethics of his profession, to professionalize himself and keep up with the socio-technological development. Regarding the teaching profession, Popovski (Поповски, 1998) points out that "there is a generally known and accepted characteristic according to which the profession teacher, as well as many others is recognizable in all contemporary democratic societies, which is, above all, its cultivation (rigorous knowledge, and general education) (Поповски, 49)."

Kyriacou (2001, according to Brkic et al., 2011) points out other factors that are the main causes for stress among teachers, such as confronting students who manifest a bad attitude towards the school and lack of motivation, disobedient students and departmental discipline in general, rapid changes in the curriculum and organization, poor working conditions, pressures related to time limits, collisions with colleagues, and a feeling of underestimation in the society as a result of the low status of the teaching profession. Boyle et al. (1995, according to Brkić et al., 2011), on the basis of empirical research, indicate that there are at least four major dimensions of exercising stress:

- Disadvantaged behaviour of students;

- Time pressure and poor working conditions;

- Need for professional recognition;

- Bad relationships with colleagues.

An earlier discussion of the causes of stress induced its multifactoriality, and many of the studies related to teaching stress have numerous definitions. Gaziel (1993), when constructing his definition of teacher stress, starts from individualization, because the stress reactions in each person are different. Worral \& May (1989) suggest that a 
person is likely to react differently to stress from time to time depending on her emotional state and the situation in which she is (according to Mk Kenzie, 2009). Regarding teacher stress, Kyriacou (1998) sets forth four main assumptions about the authenticity of defining any stress among teachers.

Stress among teachers points us to the main educational problem due to numerous reasons. When discussing the sources of stress in the teaching activity and their multifactoriality, the questions as to whether both the consequences and the effects of stress are multifactorial and whether they are related to more aspects of the teacher's life and work arise. Based on empirical research, the conclusion is that stress affects not only the teacher and his performance of his / her activity, but also the school as an organization, its professional achievements and the psychosocial status, as well as his family. If the stressors have prolonged action, then certain symptoms are associated with anxiety, depression, frustration, hostile behaviour towards students and colleagues, emotional exhaustion, and excessive tension.

The studying of life satisfaction (Diener, Lucas \& Oishi, 2002) indicates the influence and relation to subjective well-being and happiness. It is suggested that subjective well-being is a broad concept that involves the experience of pleasant emotions, low levels of negative mood and high life satisfaction.

According to "botton-down" theories, people tend to experience the responses both in a positive and negative way. Accordingly, there is a general tendency to perceive different situations positively or negatively depending on the impact of certain areas of life. These theories are focused on the personality traits, attitudes and other factors that influence the interpretation of life experiences (Diener, 1984, according to Rijavec et al., 2008, Mihalicek, 2011). Thus, these theories indicate that the satisfaction of the living areas can be greatly influenced by life satisfaction. The difference between these two theoretical views is that in the botton-up theory, the assessment of life satisfaction can largely depend on the influence of a dominant living area. For example, an individual with a high degree of satisfaction in the professional life may have high life satisfaction, provided that professional life is an important aspect of life satisfaction as a whole.

Thus, if the individual is generally satisfied with life, the living areas will be assessed more positively, unlike an individual who is generally unhappy. Diener explains that these theories are not the only causal models that explain the relational connection between life satisfaction and satisfaction from particular areas because the cause of causal connection can also be based on another variable that independently affects both components, for example, neuroticism as a factor of a person who can negatively affect life satisfaction and pleasures from different areas. Rijavec, Miljković and Brdar (2008, according to Mihalićek, 2011) point out that "life satisfaction depends to a great extent on whether we are able to choose certain goals in life and take whatever is necessary to stay on that road". The connection of life satisfaction and happiness, and in particular the requirement of happiness, is an important lifestyle. Seligman, Parks \& Steen (2006, according to Mihalićek, 2011) emphasize three ways in which people try to 
achieve happiness: a comfortable life, an engaged life and a meaningful life. Comfortable life is based on the hedonistic needs for fun, good food, drinking, buying, playing, relaxing. The engaged life is based on activities that cause a state of indulgence such as reading books, teaching, and dealing with a particular instrument, solving difficult problems, and so on. A meaningful life refers to the use of our abilities and skills for something that is greater than us - knowledge, justice, social environment, family, general good, etc.

\section{Research problem}

The main problem of this research is the examination of the connection and the extent of the expression of professional incineration, the sources of stress and the degree of their influence on the life satisfaction of the educational staff in the secondary education in the Republic of Macedonia.

The general hypothesis states that there is a statistically significant difference between the extent of the expression of professional incineration, the sources of stress and the life satisfaction of the educational staff in the secondary education that works in the cities of the interior of the Republic of Macedonia, with the exception of Skopje.

The following instruments were used in this research:

- Maslach Burnout Inventory will be used to test the level of combustion. This questionnaire is comprised of 22 questions and offered answers in the form of a six-stage Likert type.

- Scale for measuring stress sources in teachers - This scale was constructed by Boyle et al. (1995), and is adapted by Mikulandra I. and Sorić I. (2002), and translated into Macedonian for the needs of this research solely. The scale has 25 claims to be answered with the use of the five-step scale of the Likert type.

- Scale for measuring life satisfaction - A customized scale from Penezić will be used to measure the degree of animal satisfaction. This "scale" consists of 20 credits, out of which 17 credits relate to the assessment of global satisfaction while 3 audiences serve to assess satisfaction with the situation. The scale shows a high positive relationship with self-esteem and optimism, while it has a high negative link to the measures of loneliness, pessimism and anxiety of the future." (Penezić, 20). Respondents respond with the help of the fifth-degree scale of the Likert type (Penezić, 2002).

Of the total of 440 respondents, $50 \%$ are educational staff from the schools in the interior of the Republic of Macedonia, and 50\% are from the schools in Skopje. The sample is distributed equally in terms of gender structure.

Regarding the relevance of the dependent variables, the results for all respondents will first be shown in terms of the degree of expression of the level of burnout, the sources of stress and life satisfaction. 


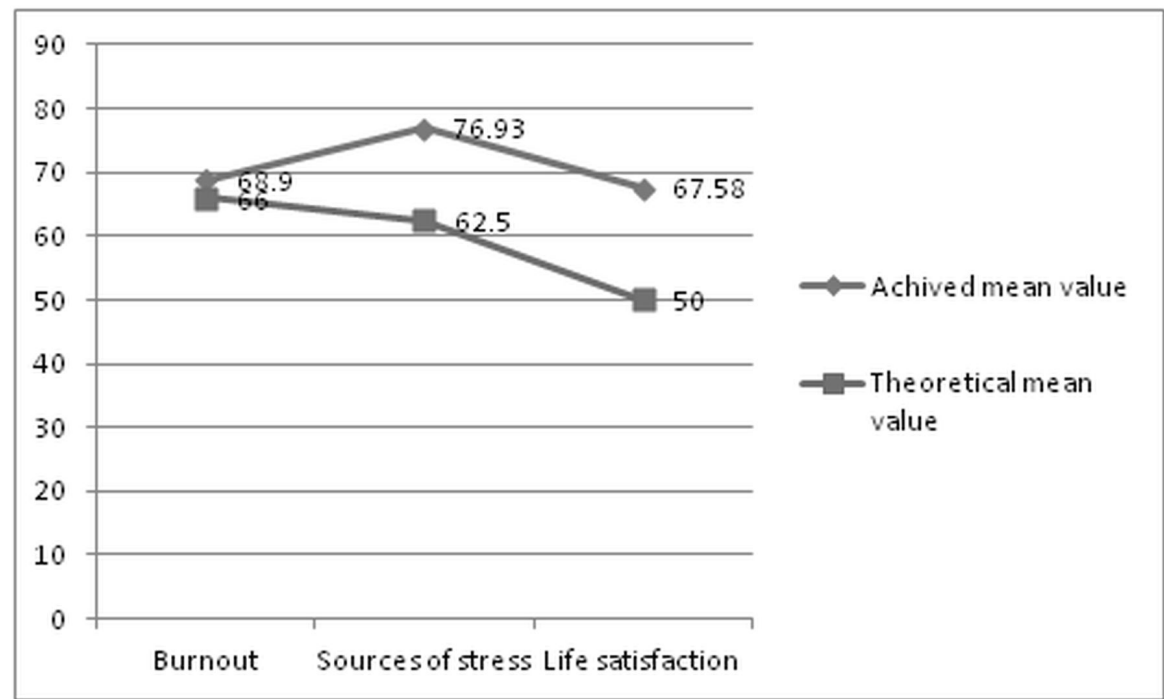

Chart 1. Difference between the scores and average expression of the scales in the burnout syndrome, the sources of stress and life satisfaction in the whole sample

Based on the data in Chart 1, the mean value of the burnout syndrome obtainned in the whole sample (68.90 to 66) indicates that it is slightly higher than the theoretical mean and likewise indicates increased burnout results. Regarding the other scales for measuring the level of stress and life satisfaction, similar results were obtained, i.e., in terms of the scale for measuring the sources of stress, the mean value was 76.93 and is higher than the theoretical level of 62.5 , which means that the respondents show higher values of experienced stress than the normal ones. The scale of life satisfaction, where the arithmetic mean is 67.58 , when compared to the theoretical mean value of 50 indicates that most examiners have higher results and feel the satisfaction of life. In all of them, a deviation of the mean value of the theoretical mean in all three tests can be noticed. 
Difference in relation to the connection and extent of professional burnout, the sources of stress and life satisfaction among the educational staff working in the cities of the interior of the Republic of Macedonia, with the exception of Skopje

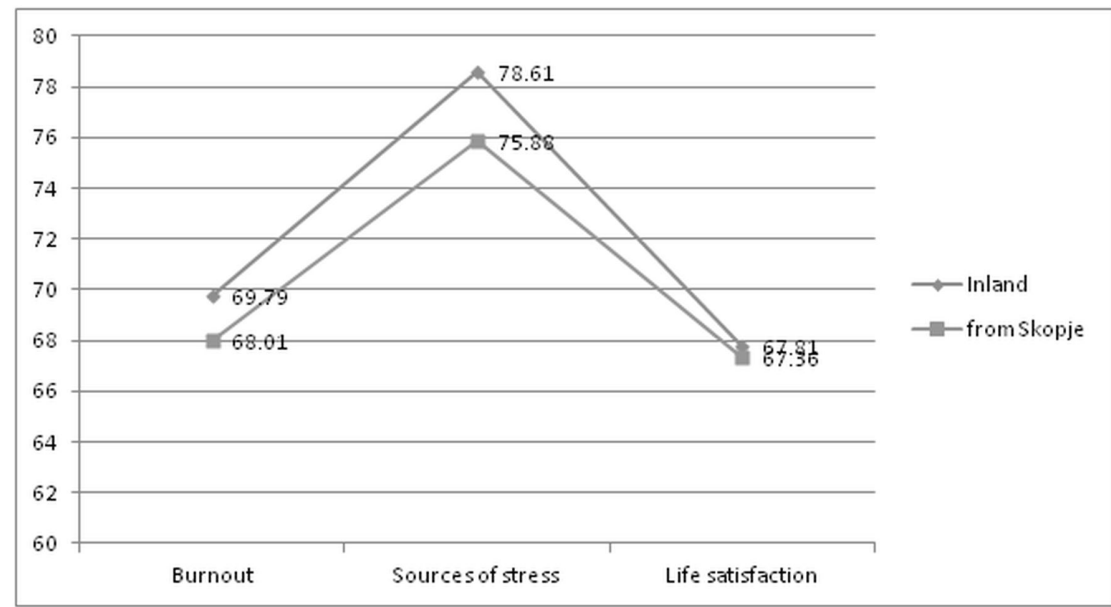

Chart 2. Range of scores and average expression of the scales in the syndrome of burnout, sources of stress and life satisfaction among the educational workers shown separately according to the location of the school within the inland and from Skopje

Based on Chart 2, it can be seen that the average results obtained in the professional burnout test and the measurement of the sources of stress are larger among the educational workers from Skopje $(M=69.79$ and $M=78.61)$ in comparison with the educators from the interior ( $M=68.01$ and $M=75.88)$, while in the test for measuring life satisfaction the arithmetic mean is lower for the educational staff from the interior $(M=67.36)$, than the one for the educational staff from Skopje $(M=67.81)$.

Based on the data obtained from the calculation of the T-test (Table 1), it can be seen that there is no statistically significant difference in the degree of expression of professional burnout, the sources of stress and life satisfaction between the educational staff working in the schools inside the Republic of Macedonia and the educational staff working in the secondary schools in Skopje. 
Table 1. The difference between the scores, the average expression of the scales and the T-test in the syndrome of burnout, the sources of stress and the life satisfaction of the educational workers shown separately according to the location of the school from the interior of the country and from Skopje

\begin{tabular}{|c|c|c|c|c|c|c|c|c|}
\hline Variables & $\begin{array}{l}\text { School loca- } \\
\text { tion }\end{array}$ & $\mathrm{N}$ & Min & Max & M & SD & $\begin{array}{c}\text { T- } \\
\text { тест }\end{array}$ & Sig \\
\hline \multirow[b]{2}{*}{ Burnout } & Inland & 120 & 44 & 116 & 68,01 & 12,541 & \multirow[t]{2}{*}{1.114} & \multirow[t]{2}{*}{0.266} \\
\hline & From Skopje & 120 & 32 & 100 & 69,79 & 12,252 & & \\
\hline \multirow{2}{*}{$\begin{array}{c}\text { Sources of } \\
\text { stress }\end{array}$} & Inland & 120 & 31 & 119 & 75,88 & 15,597 & \multirow[t]{2}{*}{1.277} & \multirow[t]{2}{*}{0.203} \\
\hline & From Skopje & 120 & 34 & 113 & 78,61 & 17,508 & & \\
\hline \multirow{2}{*}{$\begin{array}{l}\text { Life satis- } \\
\text { faction }\end{array}$} & Inland & 120 & 36 & 91 & 67,36 & 13,398 & \multirow[t]{2}{*}{.281} & \multirow[t]{2}{*}{0.779} \\
\hline & From Skopje & 120 & 38 & 91 & 67,81 & 11,307 & & \\
\hline
\end{tabular}

At the level of all three scales in relation to our population, there is no statistically significant difference in terms of the degree of expression of professional burnout, the sources of stress and life satisfaction, due to which the hypothesis is completely rejected.

\section{Discussion and conclusion}

Modern life trends followed by constant technical and technological development condition changes that are largely reflected in the educational system and its constituent components. All this also requires the acquisition of new skills and knowledge that are necessary for professional development which will enable integration of the teacher in the changed conditions of the educational system. This process of reintegrating the teaching staff in the changed conditions of the education system can cause in some of them additional stress that can be the basis for professional incineration. These changes can trigger unpleasant feelings, such as fear, tension, incompetence, loneliness, and so on. These manifestations can, to a large extent, influence the increase in stress and occupational combustion among the educational staff, which according to a number of studies indicates that they are increasingly common in the service professions, in the teaching profession in particular (Крњанић, 222).

The purpose of this study is to study the extent of the expression and the connection between the occupational combustion, the sources of stress and life satisfacti- 
on and the educational staff in the Republic of Macedonia. Given that such a survey has not been conducted on the territory of the Republic of Macedonia, this can contribute to a clearer understanding of the current state of the secondary education in the Republic of Macedonia and enable further intervening and undertaking of certain measures that will enable the reduction or elimination of the negative impacts, and thus increase the efficiency and quality of the educational process.

The basic assumption of the research is that there is a statistically significant difference in terms of the expression of professional incineration, the sources of stress and life satisfaction between the educational staff working in Skopje and the staff working in the cities in the interior of the Republic of Macedonia. In addition, the research included examination of the relevance of the basic variables of the research, the relation between the occupational combustion, the sources of stress and life satisfaction in the examined groups, and the difference regarding their expression in terms of gender, age and length of service.

In the further analysis we will discuss the results obtained in accordance with the hypothesis - there is a statistically significant difference between the degree of professional burnout, the sources of stress and the life satisfaction of the educational staff in the secondary education working in the cities in the interior of the Republic of Macedonia and the staff working in secondary education institutions in Skopje.

The basic assumption was that there is a statistically significant difference between the degree of expression of occupational combustion, the sources of stress and the life satisfaction between the educational staff working in the secondary education in the cities in the interior of the Republic of Macedonia and the educational staff working in secondary education institutions in Skopje. The results of the T-test for all three scales indicate that there is no statistically significant difference, therefore we can conclude that there is no statistically significant difference in terms of the degree of expression of occupational combustion, the sources of stress and life satisfaction between the educational staff working in the interior and the educational staff working in Skopje (Table 1), with which the established hypothesis has not been confirmed.

Permanent technical, technological and social development imposes the need to modernize the educational process and its adaptation and to monitor the continuing development trends, which will enable improvement of the quality of education. This is especially envisaged in the National Program for the Development of Education in the Republic of Macedonia 2005 - 2015. In that sense, all pedagogical staff, and especially the teaching staff, are at the centre of the contemporary endeavours for improving the quality and raising the efficiency of the pedagogical work. Within the National Program, the instruments and the conditions for monitoring and evaluating the educational work of the schools, and thus the teaching staff, are foreseen.

With this, new tasks were set before the teaching staff, which required change not only in the application of new teaching forms and technologies, but also changing the role of the teacher in the teaching process itself. This process of reintegrating the 
teaching staff in the changed conditions of the education system in some of them can cause additional stress that can be the basis for professional incineration.

In addition to the problem of occupational combustion, which greatly reduces the efficiency and quality of the teaching process, the stress of teaching is also greatly influenced, which was first seen in the eighties of the last century. Stress affects all aspects of a teacher's life such as the relationships and the communication with the students, colleagues, administration, family, and friends.

Taking into account the consequences and the negative effects that can be caused by stress and professional incineration, as well as the fact that the problem of occupational combustion in the Republic of Macedonia is very little researched, especially when it comes to education, we can say that we are at the very beginnings of this study. It is important to see to what extent can teacher stress and professional inclusion affect life satisfaction. Studying life satisfaction through studying the factors that influence the satisfaction of the work of the educational staff is particularly important, especially if we take into consideration the fact that this can directly be reflected on the quality of the educational work, the communications and the relations that the teachers establish with pupils, parents and colleagues, as well as the relations with their loved ones within the family system.

The aim of this research is to understand the degree of representation and the connection regarding the professional incineration, the teacher stress and life satisfaction among the educational staff working in the secondary education in the Republic of Macedonia and to see to what extent do other demographic characteristics, such as age, length of service and sex affect the prevalence of these phenomena. The purpose of this research is to separate the individual sources of stress that contribute to the development of stress in teachers.

The obtained results indicate that the whole sample shows higher results in terms of occupational combustion, teacher stress and life satisfaction when compared to the theoretical mean. Within the framework of the test for occupational combustion, the individual influence of the components of emotional exhaustion and depersonalisation has been investigated, which indicates that they have the greatest influence on the degree of combustion. Considering that the basic goal that was set in this research was to study the extent of the expression and the connection regarding the professional incineration, the sources of stress and life satisfaction among the educational staff in the Republic of Macedonia in relation to the location of the schools in which we can work, we conclude that there is no statistically significant difference when it comes to the three dependent variables between the educational staff working in the inland and the educational staff working in Skopje. This means that the higher results that appear among the educational staff in Skopje when compared to the ones of the educational staff from the interior are not statistically significant.

It can be seen in our research that teachers from Skopje showed higher results on the scales of occupational combustion, teacher stress, but also on the scale of life satisfaction in which the obtained data of the soup, which measures the current satisfac- 
tion, are more pronounced, but that is not the case with the scale that measures the global satisfaction according to which these teachers have shown lower values, and the resulting difference is statistically significant, which means that the inland teachers are more satisfied with the assessment of the Global pleasure. 


\section{References}

Andelković, A. (2012). Sindrom izgaranja, lokus kontrole i motiv postignuća kodprosvetnih radnika i lekara hitne pomoći. Završni-master rad, Univerzitet u Nišu.

Brkić I. et al. (2011). Izvori stresa, suočavanje sa stresom i životno zadovoljstvo učitelja razredne i predmetne nastave. Napredak 152(2) Zagreb, 211-225.

Dorman, J. (2003). Testing Model for Teacher Burnout. Australian Journal of Educational \& Developmental Psychology, Vol.3, (2003), 35-47.

Mihalček, S. (2011). Zadovoljstvo i sreća učitelja. Napredak 152(3-4) 389 - 402.

Mikulandra, I. и Sorić, I. (2002). Skala za mjerenje izvora nastavničkog stresa. Zbirka psihologijskih skala i upinika. Svezak I, Zadar: Filozofski Fakultet.

Penezić, Z. (2002). Skala zadovoljstava životom. Zbirka psihologijskih skala i upinika. Svezak I, Zbirka psihologijskih skala i upinika. Svezak I, Zadar: Filozofski Fakultet.

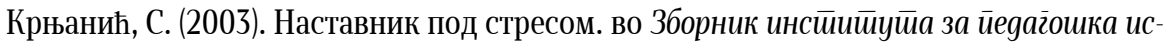
ираживања, Београд, 35, 222 - 224.

Поповски, К. (1998). Усииешен насииавник - самооценување и оценување. Скопје: Просветен работник.

Чабаркапа, М. (2009). Синдром изгарања на послу код наставника. Насӣава и васӣuйање, 2, 268-285. 